\title{
I Deserve What You Have: The Relationship Between Pattern of Envy and Achievement Motivation in Egypt: The Moderating Effect of Self-Esteem
}

\author{
Nayera Mohamed Shousha \\ Department of Psychology, Cairo University, Egypt, Cairo
}

Email address:

shou.nayera@gmail.com

\section{To cite this article:}

Nayera Mohamed Shousha. I Deserve What You Have: The Relationship Between Pattern of Envy and Achievement Motivation in Egypt: The Moderating Effect of Self-Esteem. American Journal of Applied Psychology. Vol. 9, No. 6, 2020, pp. 145-149.

doi: 10.11648/j.ajap.20200906.11

Received: October 15, 2020; Accepted: October 27, 2020; Published: November 4, 2020

\begin{abstract}
Envy is a common and complex emotion and a concept with religious specificity; however, investigating envy and its real-life outcomes is limited in Egypt. To this end, the current study examined the relationship between patterns of envy (benign and malicious) and achievement motivation. Moreover, the study examined the moderating effect of selfesteem in that relationship. A convenience sample of 248 Egyptian participants (45 men and 203 women), Mean participant age was 32.15 years (standard deviation $=9.75$ ), with an age range of 15-70 years. Participants responded to three questionnaires assessing the Benign and Malicious Envy Scale (BeMaS), The Achievement Motivation Measure (AMM) and the Rosenberg's scale for self-esteem. Results indicated that a significant positive relationship exists between benign envy and achievement motivation and with its components (Achievement thoughts and behaviors). However, no significant relationship was observed between malicious envy and achievement motivation. A significant interaction effect was observed between malicious envy and self-esteem on achievement motivation. The findings of this study will contribute to distinguishing between two patterns of envy and their outcomes through assistance in real life by improvement one's personal beliefs to reduce the negative feelings result of envy. These findings were discussed in the light of the extant theoretical and empirical literature. Furthermore, limitation and conclusion are also stated.
\end{abstract}

Keywords: Envy, Benign Envy, Malicious Envy, Achievement Motivation, Self-esteem, Egypt

\section{Introduction}

Envy is a type of negative interpersonal relation [9] associated with hostility toward others [29]. Furthermore, it can be a predictor of mental health concerns, such as stress and anxiety [10]. Envy is a complex emotion which is often related to low self-esteem and feelings of inferiority $[13,26]$. According to Webster's Online Dictionary, "envy" is derived from the Latin term invidere, which means to "look at another with malice." From this standpoint, envy can lead to negative attitudes and behaviors toward those who "cause" one to feel envy [27, 29]. Envy has mostly described as motivation hostile actions toward the others; such as harming the envied [6]. Smith and Kim defined envy as "an unpleasant and often painful blend of feelings characterized by inferiority, hostility, and resentment caused by comparison with a person or group of persons who possess something we desire." [27: p 49]. Envy can also be defined as undesirable feeling, arising from the process of comparing oneself to someone who has advantages and power, thus leading to the desire to have as much or more than what is possessed by the target of one's envy [16, 26].

Envy can be considered to be a result of a social comparison between the envier and the target of envy [15]. This social comparison occurs when Individual A (envier) perceive himself or herself to be less than Individual B (target of envy) $[8,35]$. According to Parrot and Smith, envy happens when an individual lacks or desires the qualities and achievements of others $[9,21,25,29]$. This pattern of envy is known as malicious envy, and is associated with negative and undesirable consequences $[10,29,31,32]$. Furthermore, malicious envy can trigger actions that diminish the qualities of others or hurt or by tearing down those who are envied [6, 


\section{9, 30, 32, 34], or resentful emotions [19].}

In contrast to the dominant approach in the study of envy, some researchers have posited there are more positive forms of envy. They emphasize that envy may motivate people to excel, consequently reducing the differences between them and the targets of their envy by enhancing themselves rather than by bringing others down. This is known as "benign envy," and has been shown to be associated with positive outcomes toward a talent person [10, 19, 29, 31, 32, 34]. Moreover, Gershman distinguishes between two results of envy: destructive and constructive. Malicious envy can lead to destructive results, such as frustration and anxiety, while benign envy can lead to constructive results, such as improved motivation and performance [11]. Accordingly, people with benign envy look for ways to enhance their own performance and achievements in ways that are similar to the targets of their envy, while people with malicious envy want to decrease or eliminate others' achievements $[16,26]$. The difference between consequences of benign and malicious envy reflects in the ways they motivate individuals to behave; benign envy leads to achieve the desired status and self-improvement whereas malicious envy leads to harm and take away the object of envy [19].

Although most empirical evidence relates envy with negative consequences, recent research has indicated that envy may also lead to positive outcomes such as non-hostile actions and increasing effort to self-improve [6]. Envy has been found to predict increased willingness to learn from those who one envies [29], as well as enhance motivation [5]. Additionally, envy is considered a concept with culture and religious specificity, especially in societies with an Islamic orientation, such as Egypt. Most Egyptians are convinced of the existence of envy because it is mentioned in the Holy Quran. Accordingly, religious people attribute real-life situations to envy; thus, they tend to protect themselves from envy by keeping their positive qualities hidden from others. Accordingly, the present study focused on patterns of envy (e.g., malicious and benign) and related consequences.

\section{Literature Review}

\subsection{Patterns of Envy and Achievement Motivation}

Achievement motivation (AM) can be defined as an individual's increasing effort in all actions and keeping this effort as high as possible, thus reflecting standards of superiority, competition, and excellence [28]. Atkinson and McClelland hypothesized that high achievers think, feel, and act to accomplish their goals and hope for success. Moreover, they consider what resources can help them and what obstacles might hinder their success and achievement of goals. High achievers also practice a certain set of behaviors when working toward achieving a goal, such as expecting feedback, taking moderate risks, and exploring their environment $[3,19,28]$. Moreover, one's motivation drives one's behavior [28].

As noted above, envy includes two patterns: benign envy, which can encourage individuals to improve themselves, and malicious envy, in which individuals desire to see the target of their envy fail [31]. Accordingly, achievement motivation is considered one of the constructive ways of dealing with envy. The rationale for this is that when high achievers perceive the success of others, they might feel envy. However, they then tend to excel, improve themselves, and increase competitive feelings to reduce envy [7]. Moreover, envy can lead to positive outcomes, such as motivating individuals to increase their performance or driving selfimprovement [13, 24, 25]. However, envy can lead to negative outcomes, such as a desire to hurt the target of one's envy [5, 23, 34]. Van de Ven, Zeelenberg, and Pieters showed that feeling benign envy can motivate individuals to enhance their performance and their desire to self-growth and thereby one's position [31].

Lee and Duffy reported that people who feel benign envy tend to learn from the targets of their envy by seeking advice or noticing their behaviors to achieve a level of performance similar to theirs [18]. Furthermore, Le hypothesized that benign and malicious envy involve the same process, but have different functions. Hence, Benign envy may increase motivation to be better than the target of one's envy, whereas malicious envy may decrease that motivation [17]. Accordingly, the following two hypotheses were formulated:

H1: There is positive relationship between benign envy and achievement motivation.

$\mathrm{H} 2$ : There is negative relationship between malicious envy and achievement motivation.

\subsection{Self-esteem as a Moderating Variable of the Relationship Between Patterns of Envy and Achievement Motivation}

Rosenberg defined self-esteem (SE) as an individual's overall positive appraisal to the self. Moreover, people with high selfesteem perceive themselves as worthy, effective, and deserving of respect [22]. Additionally, self-esteem is associated with personal beliefs regarding abilities, skills, personality traits, and social relationships [1]. People who have a high degree of selfesteem and positive self-evaluation are less likely to feel negative emotions such as envy, and are instead more likely to feel positive emotions [25, 29]. Previous studies have indicated that individuals with low levels of self-esteem are more likely to make upward social comparisons than individuals with high levels of self-esteem [e.g., 4, 25]. Accordingly, although individuals may respond to envy in a negative way by hurting the envied targets, they may also respond in a positive way by learning from the envied targets [29].

Kernis distinguished between two forms of self-esteem: secure and fragile. Secure self-esteem means having positive feelings toward oneself and it is stable over time. Conversely, individuals with fragile self-esteem are preoccupied with their successes and make undesirable social comparisons [14]. Accordingly, compared to people with secure selfesteem, people with fragile self-esteem are more prone to malicious envy, characterized by feelings of inferiority and hostility toward the targets of their envy. Moreover, if those 
with secure self-esteem do experience envy, they might also feel a sense of control; thus, they tend to experience benign envy [8]. We proposed that one's degree of self-esteem will influence individual tendencies toward envy, as well as patterns of envy and related consequences. Thus, a third hypothesis was formulated, as follows:

H3: Self-esteem moderates the relationship between patterns of envy and achievement motivation.

\section{Methodology}

\subsection{Sample and Data Collection}

The study used a non-probability convenience sample of 248 Egyptian participants (45 men and 203 women). Mean participant age was 32.15 years (standard deviation $=9.75$ ), with an age range of 15-70 years. Regarding education level, the majority of sample had graduated college (49.2\%), followed by postgraduate work $(46.8 \%)$, and graduating from high school $(0.4 \%)$. Participation was voluntary, and the participants were informed that their responses would be used only for scientific purposes and would remain anonymous. Thus, participants were not required to include their names on the questionnaires. The questionnaires were administered in group and single sessions in September 2020 .

\subsection{Measures}

Three questionnaires were used to measure the study variables. Lange and Crusius developed the Benign and Malicious Envy Scale (BeMaS), which comprises 10 items measuring both patterns of envy. Benign and malicious envy are assessed with five items each, such as "When I envy others, I focus on how I can become equally successful in the future," and "I feel ill will toward people I envy," respectively [16]. Responses are rated on a five-point Likert scale ranging from 1 (completely accept) to 5 (completely reject).

The Achievement Motivation Measure (AMM) is based on Atkinson and McClelland's (1957) theoretical framework on achievement thoughts and behaviors. It contains of two subscales: 9 item on achievement thoughts, such as "I feel that my present work is meaningful," and 4 items on achievement behaviors, such as "I try and follow the rule of business before pleasure." [28]. Participants responded using a five-point Likert scale ranging from 1 (completely accept) to 5 (completely reject).

Self-esteem was measured using the Arabic scale [2] based on the original version of the self-esteem scale developed by Rosenberg [22]. It includes 10 items and rated on a five-point Likert scale ranging from 1 (strongly disagree) to 5 (strongly agree).

The questionnaires were translated from English to Arabic by two bilingual individuals using the back-translation procedure. Then, a professional translator assessed the similarity between the English and Arabic forms of the questionnaire.

Furthermore, demographic variables, such as gender, age, and education level, were considered. Table 1 shows descriptive statistics and Cronbach's alpha coefficients calculated to test the reliability of the abovementioned measures.

Table 1. Descriptive statistics and Cronbach's alpha coefficients of the variables.

\begin{tabular}{llll}
\hline Variable & Mean & SD & $\begin{array}{l}\text { Cronbach's } \\
\text { alpha }\end{array}$ \\
\hline Benign and Malicious Envy Scale & 24.01 & 5.34 & 0.81 \\
Benign Envy & 15.98 & 3.94 & 0.79 \\
Malicious Envy & 8.02 & 2.80 & 0.93 \\
The Achievement Motivation Measure & 52.28 & 7.19 & 0.86 \\
Achievement Thoughts & 37.62 & 5.21 & 0.84 \\
Achievement Behaviors & 14.66 & 2.75 & 0.63 \\
Self-esteem & 36.80 & 5.85 & 0.82 \\
\hline
\end{tabular}

As seen in Table 1, most of the Cronbach's alpha coefficients were rationally high, above the recommended level of 0.70 as an indicator for high internal consistency (11).

\section{Results}

To test the first two hypotheses assuming a positive relationship between benign envy and achievement motivation and a negative relationship between malicious envy and achievement motivation, Pearson's correlation coefficients were calculated, as shown in Table 2.

Table 2. Pearson's correlation coefficients between the BeMaS and AMM.

\begin{tabular}{llll}
\hline & Envy & Benign envy & Malicious envy \\
\hline Achievement Motivation & $0.253^{* *}$ & $.326^{* *}$ & .023 \\
Achievement Thoughts & $0.206^{* *}$ & $.290^{* *}$ & -.016 \\
Achievement Behaviors & $0.270^{* *}$ & $.303 * *$ & .089 \\
\hline
\end{tabular}

${ }^{* *}$ Correlation coefficient is significant at the 0.01 level.

The results showed a significant positive relationship between benign envy and achievement motivation overall and with its components, with a $99 \%$ confidence interval. Furthermore, no significant relationship was observed between malicious envy and achievement motivation, either overall or with its components. Accordingly, the study's findings supported the first two hypotheses.

To test the third hypothesis that self-esteem moderates the relationship between patterns of envy and achievement motivation, multiple regression analysis was conducted using the standardized total scores of for patterns of envy, selfesteem, and the interaction between them as independent variables (Tables 3 and 4).

Table 3. Multiple regression analysis of the moderating effect of SE in the relationship between $B E$ and $A M$.

\begin{tabular}{lllll}
\hline $\begin{array}{l}\text { Independent } \\
\text { variables }\end{array}$ & $\begin{array}{l}\text { Regression } \\
\text { coefficient }\end{array}$ & t-value & $\begin{array}{l}\text { R- } \\
\text { squared }\end{array}$ & F \\
\hline Z-BE & 2.344 & $5.797 * *$ & & \\
Z-SE & 2.502 & $6.187 * *$ & 0.229 & $24.21 * *$ \\
Interaction & -0.411 & -0.955 & & \\
\hline
\end{tabular}

${ }^{* *}$ Correlation coefficient is significant at the 0.01 level.

Note: Dependent variable $=$ AM. 
Table 4. Multiple regression analysis of the moderating effect of SE in the relationship between $M A$ and $A M$.

\begin{tabular}{lllll}
\hline $\begin{array}{l}\text { Independent } \\
\text { variables }\end{array}$ & $\begin{array}{l}\text { Regression } \\
\text { coefficient }\end{array}$ & t-value & R-squared & F \\
\hline Z-MA & 0.886 & $2.001^{*}$ & & \\
Z-SE & 2.742 & $6.240^{* *}$ & 0.143 & $13.594^{* *}$ \\
Interaction & 0.817 & $1.939^{*}$ & & \\
\hline
\end{tabular}

${ }^{* *}$ Correlation coefficient is significant at the 0.01 level.

"Correlation coefficient is significant at the 0.05 level.

Note: Dependent variable $=$ AM.

Multiple regression analysis indicated that a slight degree of significance of interaction was observed only between malicious envy and self-esteem on achievement motivation, with a 0.05 confidence level. Thus, the third hypothesis was partially supported.

\section{Discussion}

Although the importance of envy has been indicated, Arabian psychological literature has not yet focused on this phenomenon. Therefore, the current research had two purposes: [1] to investigate the relationship between patterns of envy (benign and malicious) and achievement motivation, and [2] examine the moderating role of self-esteem in that relationship.

With respect to the first purpose, the results showed that benign envy was positively associated with achievement motivation. Additionally, no significant relationship was found between malicious envy and achievement motivation. These results were consistent with previous studies, which found that benign envy leads to improvements in performance. In addition, benign envy leads to positive consequences, such as increasing achievement motivation and the desire to improve oneself $[13,24,25,31,33]$. De Vries posited that when high achievers can feel envy toward others who are more successful than them, they use those feelings of envy as motivation to improve themselves, thus increasing competitive feelings and decrease envious feelings. Therefore, achievement motivation is considered to be a constructive way to decline feelings of envy [7]. Conversely, studies have found that malicious envy will decrease motivation, because when individuals feel a negative emotion such as malicious envy, they tend to hurt others, decreasing the qualities of their envied targets and pulling them down rather than focus on improve themselves [10, 29, 31, 32].

Regarding the second purpose, the current study found that the moderating effect of self-esteem was observed only for malicious envy, not for benign envy. The study anticipated that individuals with high self-esteem who feel malicious envy toward others would tend to be highly motivated toward achievement. This result can be explained as self-esteem is linked to positive beliefs about oneself regarding factors such as one's skills, abilities, and personality traits [1]. Additionally, previous studies have reported that people with low levels of self-esteem are more likely to make upward social comparisons than people with high levels of selfesteem [e.g., 4, 25]. Accordingly, people with low levels of self-esteem and malicious envy tend to spend much time and effort trying to tear down the targets of their envy, rather than being motivated to improve themselves. Conversely, people with high self-esteem who feel malicious feelings tend to develop positive beliefs about themselves to reduce their malicious feelings through achieving more accomplishments.

\section{Limitations and Future Research}

Although the current study contributes to the existing literature on envy, it has five limitations. First, the use of a convenience sample limits the generalization of results. Additionally, sample size is a concern in many studies, and different results could be obtained from a more diverse or larger sample. Second, the current study did not take into account the diversity in the sample (e.g., gender, age, and education level), which may have influenced the results. Third, the current study focused on the envy from the psychological aspect and did not take into consideration the religious aspect of envy especially in the Islamic religion. Fourth, although envy is widespread emotion and felt by most people, people may feel an embracement to admit their feelings of envy, so it is important to assess feelings of envy in another way except for self-report scales. Fifth, the Benign and Malicious Envy Scale (BeMaS) may not reflect the actual feelings of envy because it is loaded with social desirability, so we would suggest to observe and assess envy in a real-life situations.

\section{Conclusion}

Envy is a concept with religious specificity, and Egypt is a society with a religious orientation. The current study addressed the relationship between patterns of envy (benign and malicious) and achievement motivation, because envyespecially malicious envy - can have undesirable real-world outcomes. Moreover, in this line with the religious background of Egypt, as it is mentioned in the Holy Quran that benign envy is religiously acceptable, because the enviers do not desire to hurt others. This is in contrast to malicious envy, which is not acceptable in the Holy Quran. Furthermore, our findings revealed that benign envy is positively linked with achievement motivation, whereas malicious envy is negatively related with achievement motivation. The study also found that self-esteem moderated the relationship between malicious envy and achievement motivation that may help in real life through enhancement one's personal beliefs to reduce the negative feelings result of malicious envy. These results have important implications for differentiating between two patterns of envy by demonstrating that not all patterns of envy are negative or undesirable, for either the envier or the envied.

\section{References}

[1] Abdel-Khalek, A. M. (2016). Introduction to the psychology of self-esteem. Self-esteem: perspectives, influences, and improvement strategies, 1-17. 
[2] Abdel-Khalek, A., Korayem, A., \& El-Nayal, M. (2012). Selfesteem among college students from four Arab countries. Psychological Reports, 110, 297-303.

[3] Atkinson, J. W. (1957). Motivational determinants of risktaking behavior. Psychological review, 64 (6p1), 359.

[4] Brockner, J., Wiesenfeld, B. M., \& Diekmann, K. A. (2009). 4 Towards a "Fairer" Conception of Process Fairness: Why, When and How More may not Always Be Better than Less. The Academy of Management Annals, 3 (1), 183-216.

[5] Cohen-Charash, Y. (2009). Episodic envy. Journal of Applied Social Psychology, 39 (9), 2128-2173.

[6] Crusius, J., Gonzalez, M. F., Lange, J., \& Cohen-Charash, Y. (2020). Envy: An adversarial review and comparison of two competing views. Emotion Review, 12 (1), 3-21.

[7] De Vries, M. F. K. (1992). The motivating role of envy: A forgotten factor in management theory. Administration \& Society, 24 (1), 41-60.

[8] Duarte, J. L. (2011). The effects of scarcity and self-esteem on the experience of envy (Doctoral dissertation, Arizona State University).

[9] Eissa, G., \& Wyland, R. (2016). Keeping up with the Joneses: The role of envy, relationship conflict, and job performance in social undermining. Journal of Leadership \& Organizational Studies, 23 (1), 55-65.

[10] Erdil, O., \& Müceldili, B. (2014). The effects of envy on job engagement and turnover intention. Procedia-Social and Behavioral Sciences, 150, 447-454.

[11] Gershman, B. (2014). The two sides of envy. Journal of Economic Growth, 19 (4), 407-438.

[12] Hair, J. F., Black, W. C., Babin, B. J., Anderson, R. E., \& Tatham, R. L. (1998). Multivariate data analysis (Vol. 5, No. 3, pp. 207-219). Upper Saddle River, NJ: Prentice hall.

[13] Hill, S, E., DelPriore, D, J., \& Vaughan, P, W. (2011). The cognitive consequences of envy: attention memory, and selfregulatory depletion. Journal of personality and social psychologi. 101 (4), 653-666.

[14] Kernis, M. H. (2003). Toward a conceptualization of optimal self-esteem. Psychological inquiry, 14 (1), 1-26.

[15] Khan, A. K., Peretti, J. M., \& Quratulain, S. (2009, September). Envy and counterproductive work behaviors: Is more fairness always preferred. In 20th AGRH Conference (9th-11th Septembre 2009, Toulouse, France) of the Frenchspeaking HR/OB Research Scholarly Association.

[16] Lange, J., \& Crusius, J. (2015). Dispositional envy revisited: Unraveling the motivational dynamics of benign and malicious envy. Personality and social psychology bulletin, 41 (2), 284-294.

[17] Le, H. T. (2015). The Role of Envy in Customer Purchasing Choice with A Focus On Fashion Industry.

[18] Lee, K., \& Duffy, M. K. (2019). A functional model of workplace envy and job performance: When do employees capitalize on envy by learning from envied targets?. Academy of Management Journal, 62 (4), 1085-1110.

[19] Loureiro, S. M. C., de Plaza, M. A. P., \& Taghian, M. (2020). The effect of benign and malicious envies on desire to buy luxury fashion items. Journal of Retailing and Consumer Services, 52 .

[20] McClelland, D. C. (1965). Toward a theory of motive acquisition. American psychologist, 20 (5), 321.

[21] Parrott, W. G., \& Smith, R. H. (1993). Distinguishing the experiences of envy and jealousy. Journal of personality and social psychology, 64 (6), 906.

[22] Rosenberg, M. (1965). Society and the adolescent self- image. Princeton, NJ.

[23] Schaubroeck, J., \& Lam, S. S. (2004). Comparing lots before and after: Promotion rejectees' invidious reactions to promotees. Organizational Behavior and Human Decision Processes, 94 (1), 33-47.

[24] Schaubroeck, J., Shaw, J. D., Duffy, M. K., \& Mitra, A. (2008). An under-met and over-met expectations model of employee reactions to merit raises. Journal of Applied Psychology, 93 (2), 424.

[25] Shu, C. Y., \& Lazatkhan, J. (2017). Effect of leader-member exchange on employee envy and work behavior moderated by self-esteem and neuroticism. Revista de Psicología del Trabajo y de las Organizaciones, 33 (1), 69-81.

[26] Sitinjak, C. (2016, February). Envious increasing student's academic performance. In Proceeding from the ASEAN Conference: 2nd Psychology \& Humanity, "Optimalizing Human Strenght for Productivity and Well Being (pp. 716722).

[27] Smith, R. H., \& Kim, S. H. (2007). Comprehending envy. Psychological bulletin, 133 (1), 46.

[28] Smith, R. L., Karaman, M. A., Balkin, R. S., \& Talwar, S. (2020). Psychometric properties and factor analyses of the achievement motivation measure. British Journal of Guidance \& Counselling, 48 (3), 418-429.

[29] Tai, K., Narayanan, J., \& McAllister, D. J. (2012). Envy as pain: Rethinking the nature of envy and its implications for employees and organizations. Academy of Management Review, 37 (1), 107-129.

[30] Thompson, G., Glasø, L., \& Martinsen, Ø. (2016). Antecedents and consequences of envy. The Journal of social psychology, 156 (2), 139-153.

[31] Van de Ven, N. (2017). Envy and admiration: Emotion and motivation following upward social comparison. Cognition and Emotion, 31 (1), 193-200.

[32] Van de Ven, N., Zeelenberg, M., \& Pieters, R. (2009). Leveling up and down: the experiences of benign and malicious envy. Emotion, 9 (3), 419.

[33] Van de Ven, N., Zeelenberg, M., \& Pieters, R. (2011). Why envy outperforms admiration. Personality and social psychology bulletin, 37 (6), 784-795.

[34] Van de Ven, N., Zeelenberg, M., \& Pieters, R. (2012). Appraisal patterns of envy and related emotions. Motivation and emotion, 36 (2), 195-204.

[35] Vrabel, J. K., Zeigler-Hill, V., \& Southard, A. C. (2018). Selfesteem and envy: Is state self-esteem instability associated with the benign and malicious forms of envy? Personality and Individual Differences, 123, 100-104. 